This is the Accepted Manuscript of a book chapter published by Ashgate in Oliver Charnoz, Virginie Diaz Pedregal and Alan L. Kolata (eds). Local Politics, Global Impacts: Steps to a Multi-Disciplinary Analysis of Scales (Global Governance Series), 2015: https://www.routledge.com/Local-PoliticsGlobal-Impacts-Steps-to-a-Multi-disciplinary-Analysis/Charnoz-Pedregal/p/book/9781472460509 Accepted version downloaded from SOAS Research Online: http://eprints.soas.ac.uk/25341/

\title{
Drugs, local politics and the subversion of global counter-narcotics ideology in Burma's eastern borderlands, 1988-2012
}

\section{Patrick Meehan}

\section{Introduction}

The production, trafficking and use of illicit drugs represent a major global phenomenon. Alongside the damage this causes to individuals and societies, drugs are also perceived to be a major cause of sustained violent conflict and state fragility. Despite concerted efforts to reduce drug production and trafficking, western counter-narcotic strategies have largely been a failure. The global drugs trade continues to flourish and the US-led War on Drugs has caused substantial perverse results (Jelsma \& Kramer 2005; McCoy 2004; Tullis 1995; Van der Veen 2002). ${ }^{1}$ In the decade since the 1998 UN General Assembly Special Session on Drugs, which set 2008 as the date by which states should seek to "eliminate or significantly reduce the illicit manufacture, marketing and trafficking" (UN 1998) of drugs, global opium production grew by a staggering $78 \%$ (UNODC 2010c, 12). Over the past three decades the 2010 World Drug Report concedes that "global opium production and global coca production have grown by a factor of 6 (cocaine) and 7 (opium) during the last three decades" (UNODC 2010c, 1).

A major reason why western counter-narcotics strategies have enjoyed such little success is their poor understanding of and engagement with local politics in source countries, in particular the ways in which the drug trade has become embedded within broader processes of state-building and economic transformation. The starting point for such analysis is a political economy approach which places commodities in their social and political context and focuses explicitly on the "politics of production" surrounding resources (Nevins and Lee Peluso 2008, 2).

This study seeks to address this weakness through a detailed analysis of the political economy of the drug trade in Shan State, Eastern Burma, which is the source of $90 \%$ of Southeast Asia's opium and home to a vastly expanding production of amphetamine-type stimulants (ATS), during the period 1988-2010. It begins with a brief overview of developments in Shan State over the past two decades, emphasizing how the history of drugs in the region is one of intense interconnection, in which the drug trade has been perpetually embroiled in wider questions surrounding the autonomy of borderland populations and the distribution of power within these regions. The second section provides a brief analysis of mainstream interpretations of the relationship between drugs, conflict and state capacity which have

\footnotetext{
${ }^{1}$ Criticism of the War on Drugs has concentrated on two main issues; firstly, the failure of western counternarcotics agencies to understand the economics of the global drug trade, and secondly the huge social costs in both source and consumer countries of strict prohibition policies. Many critics have emphasized that by attempting to enforce crop eradication in source countries whilst failing to address demand for drugs in the west counter-narcotics policies have inadvertently managed to increase the 'risk premium' and thus the profitability of the drug trade, increase the volume of drugs produced by pushing cultivation into new areas beyond the reach of enforcement agencies (the 'balloon effect'), and intensify the violence surrounding the trade which in turn has caused the cost of drug enforcement to rise astronomically
} 
This is the Accepted Manuscript of a book chapter published by Ashgate in Oliver Charnoz, Virginie Diaz Pedregal and Alan L. Kolata (eds). Local Politics, Global Impacts: Steps to a Multi-Disciplinary Analysis of Scales (Global Governance Series), 2015: https://www.routledge.com/Local-PoliticsGlobal-Impacts-Steps-to-a-Multi-disciplinary-Analysis/Charnoz-Pedregal/p/book/9781472460509 Accepted version downloaded from SOAS Research Online: http://eprints.soas.ac.uk/25341/

underpinned global counter-narcotics strategies, emphasizing their limitations and making the case for an alternative approach which focuses specifically on the interrelationship between the drug trade and processes of state-building and agrarian change in Burma's borderlands. The third section analyses the specific ways in which the drug trade in Shan State has become embroiled in the dynamics of coercion, opposition and brokerage surrounding these processes. In doing so, it suggests how such 'bottom-up' approaches offer new insights into the challenges facing global governance strategies surrounding the drug trade at a time when disillusionment with the War on Drugs continues to grow. These findings are outlined in the fourth and final section.

\section{Drugs and state-building in Burma's eastern borderlands: 1988-2012}

In 1988, following decades of economic mismanagement and oppressive military rule, widespread protests engulfed much of Burma, centred on Rangoon. Following the brutal repression of these protests the new military government, the State Law and Order Restoration Council (SLORC; renamed the State Peace and Development Council (SPDC) in 1997), announced there would be free and fair elections. After the landslide victory of Aung San Suu Kyi's National League for Democracy (NLD), the SLORC ignored the election results, and instead sought to re-build its control across the country.

In many ways the late 1980s marked a nadir of state authority in Burma; insurgency remained rife throughout the country's borderlands despite decades of brutal counterinsurgency offensives, there remained widespread discontent against the government, and the state was close to bankruptcy, a fact further exacerbated by international sanctions against the country. However, new opportunities for the state's rebuilding agenda were also emerging. Within months of the state's brutal repression of the pro-democracy demonstrations, the Communist Party of Burma (CPB), Burma's largest insurgency group, collapsed and divided into four separate armies, mainly along ethnic lines, namely the United Wa State Army (UWSA) located in the Wa Hills, the Myanmar National Democratic Alliance Army (MNDAA) which controlled the Kokang area of Shan State, the Shan State Army-East (SSA-E) and the New Democratic Army-Kachin (NDA-K) based close to the Chinese border in Kachin State (Lintner 1990). ${ }^{2}$

Alongside the disarray caused by the CPB's collapse, the changing attitude of Burma's neighbours also strengthened the SLORC's state-building agenda. Under Deng Xiaoping, Chinese patronage of the CPB was terminated as China increasingly began to view Burma as a potentially useful economic ally. The country's vast natural resources became highly coveted commodities to fuel China's ongoing industrialization, whilst increasing cross-border trade was viewed as a cost-effective way to ameliorate the country's coast-interior divide by stimulating economic development in land-locked Yunnan Province. In Thailand the emergence of a powerful business class altered domestic power relations, forcing the military, which had often viewed the presence of insurgency groups on the Thai-Burma border as a useful buffer against the activities of the Burmese Army, to acquiesce to the demands of

\footnotetext{
2 The CPB, founded in 1939, was one of the first political parties to go underground (in 1948) in opposition to the Burmese government. Throughout its history it remained deeply committed to Maoist principles and the party received financial and military support from China from the mid-1960s until Mao's death (Lintner 1990).
} 
This is the Accepted Manuscript of a book chapter published by Ashgate in Oliver Charnoz, Virginie Diaz Pedregal and Alan L. Kolata (eds). Local Politics, Global Impacts: Steps to a Multi-Disciplinary Analysis of Scales (Global Governance Series), 2015: https://www.routledge.com/Local-PoliticsGlobal-Impacts-Steps-to-a-Multi-disciplinary-Analysis/Charnoz-Pedregal/p/book/9781472460509 Accepted version downloaded from SOAS Research Online: http://eprints.soas.ac.uk/25341/

political and business leaders determined to improve economic relations with Burma (MyintU 2006, 287, 308; Renard 1996, 108).

In response to these challenges and opportunities the SLORC launched a period of extensive state re-building in which for both political and economic reasons control over the country's borderland areas became increasingly important to the state's survival and development (Callahan 2007a, 17). Fears of an alliance between pro-democracy protestors fleeing central Burma and well-armed insurgent groups gave renewed urgency to the state's efforts to assert more direct control over the country's borderlands, whilst the government also realized that such control would allow it to capitalize on growing Chinese and Thai demand for the country's natural resources.

Reversing its decades-long policy of seeking a purely military solution to the insurgency it faced, the government entered into ceasefire agreements, initially with the four CPB splinter groups. By 1995 the government had signed agreements with nineteen insurgent groups (Meehan 2011, 388-9). In return for a cessation of hostilities and a promise to sever all ties with other insurgent groups the state appeared to grant ceasefire groups unofficial permission to pursue whatever business ventures they wished, the promise of economic development assistance, and entry into the National Convention to draft the country's new constitution. The ceasefire agreements did not seek to tackle the more intractable political issues surrounding the future status of the country's ethnic minority regions, and instead created a "kind of post-civil-war-not-quite-peace environment" (Callahan 2007a, xiv; TNI 2009a). ${ }^{3}$

Within this tense environment, however, the state has gained far greater control over both cross-border trade with China and Thailand and the exploitation of natural resources in the country's borderlands, predominantly through the establishment of state-private partnerships with both Burmese and foreign (especially Chinese) companies (Woods 2011a; MacLean 2008; TNI 2012). ${ }^{4}$ Within Shan State there has been a vast expansion of cash crop production, primarily rubber, but also tea, sugarcane and cassava (TNI 2012, 40-44), mineral extraction, including coal, iron, tin and precious gems (rubies and sapphires), and plans for electricity generation through the construction of numerous hydropower dams on the Salween and Shweli rivers.

Alongside these profound economic developments the government has recorded some of its most significant counter-insurgency 'victories' of the past fifty years and the state's

\footnotetext{
${ }^{3}$ The situation created by the ceasefires was by no means homogeneous. Some groups have refused to sign ceasefires, notably the Karen National Union (KNU) and the Shan State Army-South (SSA-S), and the ceasefires themselves have provided former insurgent groups with varying degrees of local autonomy. The level of autonomy granted by the state appeared to be determined by three factors. Ceasefires signed in the late 1980s and early 1990s, when the state was at its weakest, saw insurgent groups derive greater concessions than those signed later in the 1990s. Insurgent groups in control of regions with extensive natural resources have also enjoyed far greater bargaining power in their dealings with the state. Finally, those groups with powerful armies gained greater concessions as the state sought to avoid violent confrontation.

${ }^{4}$ Between 2001 and 2007 the volume of Burmese exports to China grew by 2.5 times to a value of US\$555, with Chinese imports increasing threefold over the same period (Kudo 2008, 96-97). Although illegal crossborder trade most likely continues to parallel the growth in formal trade, the state's revenue from custom duties nevertheless rose by more than 500 per cent in 2005 and rose again in 2006 (Turnell 2008, 113).
} 
This is the Accepted Manuscript of a book chapter published by Ashgate in Oliver Charnoz, Virginie Diaz Pedregal and Alan L. Kolata (eds). Local Politics, Global Impacts: Steps to a Multi-Disciplinary Analysis of Scales (Global Governance Series), 2015: https://www.routledge.com/Local-PoliticsGlobal-Impacts-Steps-to-a-Multi-disciplinary-Analysis/Charnoz-Pedregal/p/book/9781472460509 Accepted version downloaded from SOAS Research Online: http://eprints.soas.ac.uk/25341/

consolidation of power in Shan State appears to have become greater than at any time since independence. Joint offensives by the Burma Army and ceasefire groups such as the UWSA have vastly reduced the area of territory controlled by insurgency groups which refused to sign ceasefires, notably the Shan State Army South (SSA-S). In recent years the Army has also put increasing pressure on ceasefire groups that have rejected government attempts to curtail their autonomy, routing the MNDAA headquarters in Kokang in August 2009 (which resulted in some 40,000 refugees fleeing into China) and mounting offensives against the Kachin Independence Organisation (KIO) over the past year.

Throughout this period of state re-building in the borderlands, Burma's drug production, with its epicentre in Shan State, took off on an unprecedented scale (Meehan 2011, 382-3).

According to US government figures, opium levels rose from 836 to 2,340 tons between 1987 and 1995, with the area under cultivation expanding from 92,300 hectares in 1987 to 154,000 hectares in 1995 (Linter 2000, 15). The number of heroin refineries within Burma rapidly multiplied and a new network of drug-trading routes into China and India emerged (Ko Lin Chin 2009, 88-9). Although opium cultivation declined markedly in the late 1990s, the success of eradication efforts has been short-lived. Initial reduction was offset by a rapid rise in the production of amphetamine-type stimulants (ATS), an enterprise which is more footloose, less weather dependent and has an expanding market within Southeast Asia. Burma has rapidly become one of the world's leading producers of ATS and a major supplier to the growing market in China and Thailand (ALTSEAN-Burma 2006, 52-66; Ko Lin Chin 2009, 129-31). In 2009 alone, 93 million ATS pills were seized across China, Thailand and Burma (UNODC 2010a, 2). Furthermore, the opium bans launched by the MNDAA in 2002 and the UWSA in 2005, seemingly in an attempt to overcome their image in the west as 'narco-armies' and gain greater international support for their own state-building efforts, appear to have become unsustainable (Ko Lin Chin 2009, 242). In 2010 the Southeast Asian Opium Survey recorded that opium cultivation in Burma had risen for the fourth year in a row, and had grown by 76 per cent since 2009, causing Burma's share of world opium production to jump from 5 per cent in 2009 to 16 per cent in 2010 (UNODC 2010b, 11). Although production levels remain significantly below the peak years of the early 1990s, levels of production over the past five years remain similar to those estimated throughout the 1970s and 1980s (Lintner and Black 2009, 93).

In many ways the Burmese government's willingness to hold elections in November 2010 and offer limited, but significant political reforms in the period since the election appears to be a reflection of the government's growing self-confidence that it is now in a strong enough position, both politically and economically, to manage this limited democratic opening in such a way that will not threaten its control over the country. The consolidation of the state's control over the country's eastern borderlands has been essential to this growing assertiveness.

\section{Drugs, conflict and state fragility: A review of the literature}

The dominant discourse on the political economy of illicit drugs has been underpinned by two inter-related arguments; firstly, that drugs are a major cause of sustained violent conflict, and secondly that they play a fundamental role in increasing state fragility. 
This is the Accepted Manuscript of a book chapter published by Ashgate in Oliver Charnoz, Virginie Diaz Pedregal and Alan L. Kolata (eds). Local Politics, Global Impacts: Steps to a Multi-Disciplinary Analysis of Scales (Global Governance Series), 2015: https://www.routledge.com/Local-PoliticsGlobal-Impacts-Steps-to-a-Multi-disciplinary-Analysis/Charnoz-Pedregal/p/book/9781472460509 Accepted version downloaded from SOAS Research Online: http://eprints.soas.ac.uk/25341/

\section{Drugs and conflict}

The drugs-conflict nexus emerged out of a wider body of literature in the 1990s that was interested in why the end of the Cold War had failed to deliver a prolonged peace dividend and what factors continued to drive war (predominantly intra-state war) in the Global South following the decline of Cold War superpower patronage. This literature focused specifically on the economic dimensions of war, especially their self-financing nature (Hirshleifer 1995, 2001; Ballentine and Sherman 2003; Ballentine and Nitzschke 2005; Collier 2000; Berdal and Malone 2000; Keen 1998; Grossman 1991). Following the influential work of Paul Collier and Anke Hoeffler (1998; Collier et al 2003) growing attention has focused on the relationship between resource abundance and violent conflict. Violence has been conceptualised as rent-seeking predation, with the plunder of natural resources being understood as the underlying driving force in most contemporary civil wars.

Drugs have been considered an especially conflict-prone resource for a number of reasons. Firstly, they are an inherently lootable resource; they can be extracted by individuals or small groups without the use of expensive equipment and can be easily smuggled, preventing states from monopolising production or preventing extraction (Ross 2004; Lujala et al 2005, 539; Snyder 2005). Such lootability also allows rebel leaders to provide credible material incentives for fighting, increasing soldier recruitment and solving the problem of collection action. Secondly, the illicit nature of drugs is also presumed to make them especially predisposed to conflict (Cornell 2005). A thriving drug economy is deemed to require the creation of ungoverned spaces based on the presumption that greater state control would entail a clamp down on illegal activities and might lead to interference with cross-border networks to lucrative foreign markets. These arguments were epitomised most clearly in the UNODC 2010 World Drug Report which argued that,

Large-scale opium poppy cultivation requires large land areas, and is a highly labour-intensive activity. To generate the heroin needed to satisfy global demand, thousands of hectares and hundreds of thousands of workers must be employed without state interference, and the best deterrent for state interference with this process is a rebel army. Without an active conflict, heroin production can be eliminated (UNODC 2010c, 232).

The illicit nature of drugs may make a peaceful resolution harder to achieve because the need to maintain legitimacy within the international system is believed to discourage states from offering any form of negotiated settlement with rebel groups that could allow them to retain some form of control over the drug trade. As a consequence the opportunity cost of peace becomes extremely high for rebel groups involved in drugs, and may discourage them from seeking a durable political settlement. Finally, the risk premium attached to the production and trafficking of illicit narcotics make them an especially profitable resource, which is perceived to increase the likelihood that the initial grievances of insurgent groups located in drug-producing regions may be more easily corrupted (Cornell 2005, 758). The long-running insurgency in Burma and the activities of the FARC in Colombia are often viewed as paradigmatic examples of the corruptive capabilities of drug revenues and the challenges this poses to establishing a durable peaceful resolution (Cornell 2005; Brown 1999). 
This is the Accepted Manuscript of a book chapter published by Ashgate in Oliver Charnoz, Virginie Diaz Pedregal and Alan L. Kolata (eds). Local Politics, Global Impacts: Steps to a Multi-Disciplinary Analysis of Scales (Global Governance Series), 2015: https://www.routledge.com/Local-PoliticsGlobal-Impacts-Steps-to-a-Multi-disciplinary-Analysis/Charnoz-Pedregal/p/book/9781472460509 Accepted version downloaded from SOAS Research Online: http://eprints.soas.ac.uk/25341/

\title{
Drugs and state fragility
}

The 1990s also witnessed renewed interest in the role that the state could play as an agent for development and a belief that overcoming state fragility in the developing world should be a priority for international development agencies. Illicit economies have been viewed as both a sign and a cause of state fragility, embodying a major security threat to the west by creating ungoverned spaces in which transnational crime and terrorism could flourish (For example: E.U. 2005). As David Nugent (1999) argues, "illegal networks are usually taken to point to the limits of the state...[and]... are generally seen to reflect and/or fill a void in state activities, to point to an absence or at least a 'thin-ness' in 'stateness"',(pp.68-9; see also Goodhand 2008b, 413).

Together these two suppositions have created the dominant perception that drugs have contributed to a vicious cycle of conflict and ever-weakening state capacity. A powerful symbiotic relationship is thus perceived to exist between counter-narcotics strategies, peacebuilding and state-building, with strict law enforcement and drug eradication portrayed as a means by which to target the revenue of 'greedy' rebels and in doing so strengthen government institutions in fragile states.

\section{The drugs-conflict-state fragility nexus: $A$ critique}

The ongoing prevalence and diversification of drug production in Shan State over the past two decades greatly complicates standard interpretations of the factors fuelling the drug trade, especially since the locations where drug cultivation has grown most rapidly since 2006 appear to be in areas that have come under increasing state control (PWO 2006; TNI 2012). The duality of drug production and state consolidation in Burma's borderlands strongly suggests that drugs should no longer be portrayed as existing only in the murky underworld of 'greedy' rebels, organized crime and terrorists operating in ungoverned spaces beyond the reach of the state, and nor should they be viewed as necessarily perpetuating state fragility. An alternative conceptual framework is needed, which engages with the "politics of production" (Nevins and Lee Peluso 2008, 2) and acknowledges that it is not the presence of resources themselves, but the social relations surrounding them that determine the relationship between resources, conflict and state capacity (Meehan 2011, 402; van der Veen 2002, 104; Goodhand 2008b). Such an approach must engage with the complex dynamics of state-building and economic transformation within the specific spatial dynamics of borderland regions. Moving beyond simplistic rebel-centric approaches, it is argued that the drug trade in Burma's eastern borderlands is shaped by the motivations and actions of multiple actors who engage in a complex and fluctuating mosaic of coercion, countermovement and brokerage in response to the processes of state consolidation and economic transformation which are profoundly shaping life in these borderlands.

\section{State-building and economic transformation in Burma's borderlands}

\author{
State-building and the institutionalization of order \\ "Mainstream state talk" (Boege et al 2008, 4) has typically analysed fragility in terms of the \\ extent to which state institutions embody or deviate from a set of supposed state norms, \\ modelled on the specifically western development trajectory of the classical
}


This is the Accepted Manuscript of a book chapter published by Ashgate in Oliver Charnoz, Virginie Diaz Pedregal and Alan L. Kolata (eds). Local Politics, Global Impacts: Steps to a Multi-Disciplinary Analysis of Scales (Global Governance Series), 2015: https://www.routledge.com/Local-PoliticsGlobal-Impacts-Steps-to-a-Multi-disciplinary-Analysis/Charnoz-Pedregal/p/book/9781472460509 Accepted version downloaded from SOAS Research Online: http://eprints.soas.ac.uk/25341/

Weberian/Westphalian state (Midgal 2001, 3-16). ${ }^{5}$ Such an approach conceptualises the model state as a single actor functioning autonomously over society and wielding a monopoly over the legitimate use of violence within a clearly defined territorial unit. The liberal statebuilding agenda has sought to overcome state fragility by supplanting western institutions which, it is argued, will increase state capacity and allow states in the developing world to overcome the threat of violent disorder and economic underdevelopment (Ghani and Lockhart 2008). Within this model of "virtuous state-building" (Giustozzi 2001, 5), the perceived correlation between thriving illicit economies and state fragility is primarily founded upon a number of implicit "normative dualisms" (Ballve 2011, 10), notably between state and non-state actors and licit and illicit activities, which equate the state with law and order and relegate illicit activities to the status of a 'deviant subculture' (Heyman and Smart 1999, 19; Meehan 2011, 378;). This approach, however, is highly problematic as the perception that criminal networks mark the frontier of state authority, appear to reflect underlying normative assumptions surrounding the 'correct' role of the state, rather than an accurate empirical analysis of the political economy of illicit commodities in source countries, and the role that they play in processes of state-building and state breakdown. As Jennifer Milliken and Keith Krause (2002) argue, "concern over the possibility of state failure thus often has as much to do with dashed expectations about the achievement of modern statehood, or the functions that modern states should fulfil, as it does with the empiricallyobserved decomposition or collapse of the institutions of governance in different parts of the world" (pp.753-4 ).

Such normative approaches to state-building are unable to account adequately for contexts in which the lack of Weberian foundations has not created state fragility or led to state breakdown. Between the Kantian/Rawlian virtuous state and the Hobbesian anarchic dystopia exists a vast array of functioning state institutions. A far more interesting and important starting point for analysis is how states function in spite of lacking the institutional foundations of western states. This necessitates an engagement with how states actually function, rather than how they ought to (Heyman and Smart 1999; Lund 2006, 674). It requires moving beyond the 'idea' of the state and instead engaging with its empirical reality (Abrams 1988).

In Burma's drug-producing borderlands, as across large parts of the world, Weberian foundations quite simply do not exist. Instead, Shan State remains embroiled within the "brutal politics of sovereignty" (Goodhand 2009, 9). It contains contending and competing centres of legitimacy and public authority and state-like institutions are not managed by a single actor ('the government') but are controlled by an array of competing social groups. There is no central monopoly over the means of violence, which is instead dispersed throughout society. The fundamental question, which lies at the heart of understanding a country's specific development pathway, is how state institutions are constructed and how

\footnotetext{
${ }^{5}$ Migdal (2001) offers a lengthy critique of this approach, arguing that the fixation with Weberian definitions of the state offers "no way to theorize about arenas of competing sets of rulers, other than to cast these in the negative, as failures or weak states or even non-states. In short Weber's ideal state when taken as the normal state obscures as much as it illuminates by consistently measuring actual states against an ideal version of what states should be" (15).
} 
This is the Accepted Manuscript of a book chapter published by Ashgate in Oliver Charnoz, Virginie Diaz Pedregal and Alan L. Kolata (eds). Local Politics, Global Impacts: Steps to a Multi-Disciplinary Analysis of Scales (Global Governance Series), 2015: https://www.routledge.com/Local-PoliticsGlobal-Impacts-Steps-to-a-Multi-disciplinary-Analysis/Charnoz-Pedregal/p/book/9781472460509 Accepted version downloaded from SOAS Research Online: http://eprints.soas.ac.uk/25341/

order is institutionalised in such areas where the central state has no a priori monopoly over the means of violence, in which the legitimacy and exercise of public authority is widely dispersed and in which processes of centralisation are constantly challenged.

In states where sovereignty remains "fragmented" efforts to establish order, manage violence, define property rights and control access to resources are rarely the result of formal institutional frameworks (Lund 2011), but instead emerge from intense bargaining processes between an array of societal actors. These bargaining processes are rooted in the politics of patrimonialism (De Waal 2009) and are focused on creating incentive structures that will encourage groups to pursue their aims through peaceful means rather than through violence. Understanding the role that such bargaining processes play in state-building and state breakdown necessitates adopting a "coalitional analysis", which focuses on the "shifting constellations of power that underpin formal and informal institutional arrangements that govern the exercise of different forms of authority within society", and the role that resources play in shaping such coalitions (Di John 2008, 35).

One of the most effective ways for central government actors to create effective coalitions may be to create what Douglass North et al. (2007 and 2009) have best described as a 'limited access order'. In limited access orders, the political system manipulates the economic system and powerful non-state actors are given access to valuable political and economic rents in an attempt to gain their loyalty and encourage them to co-operate with each other rather than to fight. By offering preferential access to these resources it becomes possible to form coalitions between actors which may otherwise have had little incentive to co-operate. Political and economic structures are thus designed primarily to create the rents which "provide[...] the glue that holds the coalition together, enabling elite groups to make credible commitments to one another to support the regime and perform their functions" (North et al 2007, 8).

Controlling access to resources plays an extremely important role in the creation of limited access orders. This insight emphasizes the need for a far more complex and empirically grounded political economy of illicit economies in weak states that moves beyond the confines of the current literature on the 'resource curse'. Indeed, the illicit and lucrative nature of drug economies may make them highly predisposed to the creation of rents and thus a valuable means through which to establish limited access orders. The illicit nature of the drug trade provides the state with an array of 'sticks' and 'carrots' with which to coerce and co-opt private actors over which it would otherwise have little authority. It provides the state with an opportunity to prosecute those involved in the drug trade, often in collaboration with international counter-narcotics agencies, and to legitimate repressive policies against groups involved in the trade, regardless of whether such policies are motivated by efforts to curtail narcotics production. At the same time the state's ability to protect and support groups involved in the trade by offering legal impunity, money laundering services and access to foreign markets via government-controlled transport networks and border checkpoints, can create a system of rents with which to build coalitions. Where the state is able to utilise such incentives and threats "institutions of joint extraction" (Snyder 2006) may emerge between 
This is the Accepted Manuscript of a book chapter published by Ashgate in Oliver Charnoz, Virginie Diaz Pedregal and Alan L. Kolata (eds). Local Politics, Global Impacts: Steps to a Multi-Disciplinary Analysis of Scales (Global Governance Series), 2015: https://www.routledge.com/Local-PoliticsGlobal-Impacts-Steps-to-a-Multi-disciplinary-Analysis/Charnoz-Pedregal/p/book/9781472460509 Accepted version downloaded from SOAS Research Online: http://eprints.soas.ac.uk/25341/

state and non-state actors and illicit economies may actually become a means through which to establish political coalitions.

Significant gaps, however, remain in the understanding of how limited access orders actually function. The role that illicit economies play in establishing coalitions remains especially limited as do insights into the factors which determine the durability of political coalitions, the conditions that cause them to become fragile and collapse, the extent to which they strengthen the state or lead to a permanent dispersion of power and sovereignty, and finally the factors which determine why some limited access orders are able to promote social and economic development whilst others register few positive developments other than a temporary and partial reduction in levels of violence (Di John 2008, 31-2). Furthermore, despite the fact that coercive power is widely dispersed in 'limited access orders', much of the literature on the political economy of state-building deals inadequately with issues of space and scale and as result offers only a partial and simplified analysis of how political coalitions emerge in sub-national spaces and how they are shaped by the specific dynamics of borderland regions. Importantly, there is also limited engagement in how such bargaining processes are affected by concurrent processes of agrarian change in areas, like Burma's borderlands, which are experiencing the increasingly intense impact of economic globalisation and are undergoing profound economic transformation as a result. ${ }^{6}$ Addressing these weaknesses offers a far more nuanced and insightful analysis into how coalitions are established and the important role that drugs play in their establishment in Shan State.

\section{Borderland dynamics}

Borderland regions provide a specific set of spatial dynamics which can, as in Burma's case, decisively shape the construction of limited access orders. 'Borderlands' embody spatial zones, defined here on the basis of two criteria. Firstly, they are areas in which the 'border effect' of international boundaries impacts upon the mentalities and political and economic activities of their populations. Secondly, drawing on the notion of "internal borderlands" (Goodhand 2008a, 228), they may also be defined as areas of weak state penetration. They represent zones of hybridity in which the state often faces great difficulty in imposing its sovereignty, either through infrastructural or despotic power (Mann 1984). ${ }^{7}$ They have often been misleadingly projected as uncivilized, passive zones at the margins of state formation, subject to a linear and irreversible process of state encroachment and state-centring. As Neil Brenner (1999) rightly argues, "territorialization is thus represented as a natural precondition

\footnotetext{
${ }^{6}$ North et al's (2009) analysis also overlooks the fact that decision-making may be a collective rather than individual process and may be affected by identities, emotions (such as pride, hatred, fear, shame and distrust), past decisions, belief systems, attachment to place, and the wider social networks in which actors are situated. Their contention that that coalitions only become stable when the "political interests of coalition members are balanced by their economic stakes in the existing order" (p.42) and are dependent on increasing the "rents from peace", defined as "the difference in the returns their assets earn when they do not fight compared to the returns they earn when they do fight" (p.19), appears to partially reduce coalition members to rational utility maximisers. In doing so their analysis is in danger of inadequately capturing the multiple factors which may determine the motivations and incentive structures underlying bargaining processes.

${ }^{7}$ Despotic power embodies the state's abilities to impose forcible control 'over society' and represents the repressive capabilities of the state. Infrastructural power represents the state's power to penetrate society and implement its decisions. It is seen to require a degree of cooperation and engagement between rulers and citizens with the state governing 'through society' (Mann 1984).
} 
This is the Accepted Manuscript of a book chapter published by Ashgate in Oliver Charnoz, Virginie Diaz Pedregal and Alan L. Kolata (eds). Local Politics, Global Impacts: Steps to a Multi-Disciplinary Analysis of Scales (Global Governance Series), 2015: https://www.routledge.com/Local-PoliticsGlobal-Impacts-Steps-to-a-Multi-disciplinary-Analysis/Charnoz-Pedregal/p/book/9781472460509 Accepted version downloaded from SOAS Research Online: http://eprints.soas.ac.uk/25341/

of social and political existence rather than being seen as a product of historically determinate strategies of parcelization, centralization, enclosure, and encaging" (p.49; for a further critique see: Agnew and Corbridge 1995, 78-102; Baud \& Schendel 1997; Goodhand 2008a; Agnew 2008, 180; Newman and Paasi 1998, 196). This has overlooked both the importance of borderlands to the construction of the modern state and the historical processes through which territorial sovereignty in these areas has emerged. In doing so it has given inadequate attention to the role that the margins can play in shaping political developments at the centre (Goodhand 2008a). This is especially problematic in the case of Burma, where the country's drug-producing eastern borderlands have become an increasingly central part of the government's state-building agenda over the past twenty years.

Territorialising borderlands confers upon the state a number of opportunities. Most importantly, the state's ability to control the opening/closing of the border is an essential foundation for the construction of limited access orders. Without the power to enclose powerful non-state actors, the logic which underpins limited access orders cannot be operationalised since the state's claims to offer preferential access to valuable political and economic rents may be subverted by non-state actors' recourse to cross-border sources of patronage. It is only through the creation of a territorially enclosed state that the incentive for non-state actors to co-operate with the centre is likely to become strong enough to enable the creation of durable political coalitions. By managing the border the state therefore finds itself in a much stronger position to breakdown cross-border political networks which threaten to subvert its sovereignty and force borderland actors to look inwards.

Borders themselves can be understood as valuable economic resources since the control and taxation of cross-border trade can strengthen the state's financial position. Controlling the border may also allow the state to benefit from inflows of transnational finance into borderland regions and may even transform these flows into economic rents with which to construct limited access orders. Controlling the border also enables the state to construct and deconstruct certain social, political and economic boundaries by managing cross-border flows of people and goods and defining the rules for inclusion and exclusion in the political community. This can promote the development of national identities in which citizens become defined by their relation to the territorial state and its institutions.

Borderlands, however, also embody zones of insecurity, paranoia and endanger the construction of the modern state. James C Scott's conceptualization of borderlands as zones of hybridity and resistance provides the clearest insight into the challenges the state faces in these spaces (Scott 2009). He argues that borderlands may commonly embody zones of refuge or "shatter zones" (p.325) which are best understood as anti-state spaces defined by activities and ideologies designed explicitly to repel the centripetal forces of the state's 'civilising mission'. Indeed, he argues that the very profile of borderland societies - low population density, extensive agriculture, linguistic and ethnic diversity - has developed in response to efforts by the state to control them.

Finally, it is in the borderlands, where identities and affiliations straddle cartographic boundaries, that the state's efforts to create a territorially defined nation state are revealed most starkly as illusory. This may be especially true in post-colonial late developing 
This is the Accepted Manuscript of a book chapter published by Ashgate in Oliver Charnoz, Virginie Diaz Pedregal and Alan L. Kolata (eds). Local Politics, Global Impacts: Steps to a Multi-Disciplinary Analysis of Scales (Global Governance Series), 2015: https://www.routledge.com/Local-PoliticsGlobal-Impacts-Steps-to-a-Multi-disciplinary-Analysis/Charnoz-Pedregal/p/book/9781472460509 Accepted version downloaded from SOAS Research Online: http://eprints.soas.ac.uk/25341/

countries where "most states are 'younger' than the societies they purport to administer and the demarcation of borders preceded nation-building" (Goodhand 2008a, 228). It is within the borderlands that various political geographies are most clearly in conflict. To adapt Arjun Appadurai's (2001) terminology, it is in the borderlands that the state's efforts to operationalise "trait geographies", best defined as the attempt to affix specific attributes to a given space (national identities, language, relations to the state), come up most sharply against the "process geographies" of many societies, in which human organization is the result of "various kinds of action, interaction, and motion - trade, travel, pilgrimage, warfare, proselytization, colonization, exile, and the like" (7-8), none of which fit easily within the spatial container of the state.

The borderlands thus embody a specific set of dynamics around the generation of capital, the means of coercion, and the legitimization of state power, which are integral to processes of state formation (Tilly 1990; see Table 1). The state's management of the borderlands is therefore a fundamentally important dynamic of state formation and provides an important entry point for analyzing the political processes shaping Burma's drug-producing regions.

Table 1: Borderlands as zones of opportunity and risk

\begin{tabular}{|l|l|l|}
\hline Opportunity & Risk \\
\hline Capital & $\begin{array}{l}\text { Strengthening of the state's } \\
\text { economic position through: } \\
\text { - Taxation of cross-border } \\
\text { trade. }\end{array}$ & $\begin{array}{l}\text { Taxation of revenue from } \\
\text { cross-border trade, from } \\
\text { resources in the borderlands } \\
\text { - Extraction, or taxation of } \\
\text { extraction of resources } \\
\text { transnational capital may } \\
\text { afford non-state actors } \\
\text { - Taxation of borderland } \\
\text { populations. } \\
\text { - Management of } \\
\text { transnational capital. }\end{array}$ \\
\hline \multirow{2}{*}{ Coercion } & $\begin{array}{l}\text { state. This may lead to the } \\
\text { breakdown of limited access } \\
\text { orders and may fund violent } \\
\text { opposition to the state. }\end{array}$ \\
\hline $\begin{array}{l}\text { The ability to open/close the } \\
\text { border is an important } \\
\text { foundation for establishing a } \\
\text { limited access order by } \\
\text { forcing force non-state actors } \\
\text { to engage with the centre. }\end{array}$ & $\begin{array}{l}\text { Cross-border networks of } \\
\text { patronage and access to } \\
\text { alternative power centres } \\
\text { break down the logic of the } \\
\text { limited access order. This } \\
\text { strengthens the bargaining } \\
\text { position of borderland actors } \\
\text { vis-à-vis the state. }\end{array}$ \\
\hline $\begin{array}{l}\text { Control of the borderlands } \\
\text { allows the state to provide } \\
\text { services and welfare and to } \\
\text { "set the limits of acceptable } \\
\text { political, economic and } \\
\text { social behavior" (Taylor, }\end{array}$ & $\begin{array}{l}\text { Social identities that } \\
\text { transcend the territorial state } \\
\text { undermine the notion of the } \\
\text { state as the container of } \\
\text { society; The porosity of } \\
\text { borderlands may encourage }\end{array}$ \\
\hline
\end{tabular}


This is the Accepted Manuscript of a book chapter published by Ashgate in Oliver Charnoz, Virginie Diaz Pedregal and Alan L. Kolata (eds). Local Politics, Global Impacts: Steps to a Multi-Disciplinary Analysis of Scales (Global Governance Series), 2015: https://www.routledge.com/Local-PoliticsGlobal-Impacts-Steps-to-a-Multi-disciplinary-Analysis/Charnoz-Pedregal/p/book/9781472460509 Accepted version downloaded from SOAS Research Online: http://eprints.soas.ac.uk/25341/

2008, p.11); It allows the
state to define social
boundaries of
inclusion/exclusion and to
build national identities, in
which citizens are defined by
their relation to the territorial
state and its institutions.

multiple frameworks of selfidentity, leading to the rejection of nation-building strategies and undermining the state's efforts to establish homogeneity.

\section{Processes of economic transformation}

State-building processes in Burma's eastern borderlands have been further complicated by the expansion of capitalist market relations and the rapid growth of international trade and transnational capital flows over the past twenty years. The increased demand and competition for land and resources have intensified processes of commoditization, best defined as the "transformation of people and "nature' into marketable products" in which "everything comes to acquire a price and monetary form" (Nevins and Lee Peluso 2008, 3, 14-15). Across Southeast Asia these processes are not new. Commoditization has a long history dating back to pre-colonial trade networks that traversed the region and intensifying through the colonial period. However, over the past thirty years increased levels of technology, science and infrastructure, the huge growth in demand for resources, predominantly from China, and the development of increasingly strong post-colonial states that have been able to support, and in some cases lead, processes of enclosure and primitive accumulation, have meant that the impact of commoditization has been especially transformative. The fact that Burma's drug-producing regions contain a vast array of other highly coveted natural resources has meant that the impact of these processes has been particularly profound.

Understanding the impact of commoditization requires moving beyond the "civilizing frontier rhetoric" (Cramer and Richards 2011, 289), in which commoditization is commonly portrayed as an inherently positive foundation for economic development conducted upon pre-modern spaces. The commoditization of space is not the result of a gradual extension of property right structures and market relations into wild, previously ungoverned frontier zones but instead entails complex processes of agrarian change involving the destruction of existing social and economic structures in order to create new economic orders (Peluso and Lund 2011, 668). Commoditization is thus underwritten by the 'de'territorialization and 're'territorialization of rural spaces; it is founded upon "rescaling access to the commons, and...institutionalizing new processes of inclusion and exclusion in rural political economies" (Barney 2008, 106). It involves the destruction of existing land uses, property rights structures and social relations and the establishment and entrenchment of new property right regimes. The inherent inequality and injustice underpinning the primitive accumulation of capital, has meant that such processes are invariably heavily contested and has ensured that extreme violence has often been a means with which to both "open up" areas and "discipline" populations, and to try to counteract these processes (Nevins and Peluso 2008, $3)$.

Developing an analytical framework which assesses the dynamics of state consolidation and economic transformation within borderland spaces provides the basis for understanding the 
This is the Accepted Manuscript of a book chapter published by Ashgate in Oliver Charnoz, Virginie Diaz Pedregal and Alan L. Kolata (eds). Local Politics, Global Impacts: Steps to a Multi-Disciplinary Analysis of Scales (Global Governance Series), 2015: https://www.routledge.com/Local-PoliticsGlobal-Impacts-Steps-to-a-Multi-disciplinary-Analysis/Charnoz-Pedregal/p/book/9781472460509 Accepted version downloaded from SOAS Research Online: http://eprints.soas.ac.uk/25341/

geographically and historically specific trajectory of state consolidation in Burma over the past twenty years. It offers insights into the alignment of the interests of the state and of capital in pursuing spatial strategies focused on producing manageable territory in the country's borderlands. Such an analysis also emphasizes how such territorial control cannot be taken as pre-given or abstract form of the state but is determined by ongoing processes and strategies which remain highly contested (Massey 2009, 17; Brenner and Elden 2009).

\section{Coercion, countermovement and brokerage: Re-considering the political economy of drugs}

The profound political, economic and socially dislocating developments in Burma's borderlands, over which the drug trade has become a palimpsest, have, however, rarely featured in policy analysis. Counter-narcotics strategies have instead tended to assume that strengthening the capacity of the state and promoting alternative forms of economic development will automatically lead to a reduction in drug production, rather than considering how state-building strategies and economic transitions may actually interact with and re-shape the drug trade. Overcoming these inherent analytical weaknesses requires adopting an alternative approach, which engages with how the drug trade is both shaped by and continues to shape the region's political and economic trajectories and how it has become embedded within the multiple and overlapping processes of coercion, counter-movement and brokerage that surround state-building strategies and processes of economic transformation.

\section{Coercion}

Henri LeFebvre's ([1974], 1991) assertion that the modern state is a form of "violence directed towards a space" (280), designed to create a unified and homogenous society within a space that "has nothing homogenous about it" (308) captures the essence of how state territorialisation - the creation of state-controlled spaces - is a political construct and one prone to violent conflict. The drive for homogenization is founded upon the state's desire to make societies and cultures more easily 'legible' and 'governable', in order to control populations and impose regularised systems of taxation and land ownership (Scott 1998). By establishing territorial control the state determines access to and control over land and resources, "produc[ing] and maintain[ing] power relations among environmental subjects and between subjects and authorities", and as a result is likely to be heavily contested (Peluso and Lund 2011, 673). The use of violent coercion is often central to the processes in which such power relations are imposed and rejected (Giustozzi 2011; Cramer 2006).

Within Shan State, drug economies have clearly been co-opted to finance the coercive practices which underpin state-building and economic change. Pervasive militarisation of the borderland regions has become instrumental to the state's renewed efforts to extend its territorial control. This policy of increased militarisation has, however, only been partly financed by the central government. The Army has instead been required to 'live off the land', a policy which became explicit in 1997 when the government's War Office informed the Army's twelve Regional Commanders that troops "were to meet their basic logistical needs locally, rather than rely on the central supply system" (Selth 2002, 136; Callahan $2007 \mathrm{~b}, 46)$. The ability of the state to pursue "coercion-intensive" forms of state consolidation (Tilly 1990) has thus been directly reliant upon the Army's ability to generate revenues locally. In Shan State, the taxation of opium cultivation and trafficking appears to 
This is the Accepted Manuscript of a book chapter published by Ashgate in Oliver Charnoz, Virginie Diaz Pedregal and Alan L. Kolata (eds). Local Politics, Global Impacts: Steps to a Multi-Disciplinary Analysis of Scales (Global Governance Series), 2015: https://www.routledge.com/Local-PoliticsGlobal-Impacts-Steps-to-a-Multi-disciplinary-Analysis/Charnoz-Pedregal/p/book/9781472460509 Accepted version downloaded from SOAS Research Online: http://eprints.soas.ac.uk/25341/

have become an important way in which to fund this decentralized system of military financing, creating a system whereby whilst the central government continues to work with the UNODC in promoting counter-narcotic strategies, at the sub-national level, army personnel continue to use the drug trade as means through which to finance their activities in the borderlands (PWO 2010, 2011; SHAN 2003, 2005; TNI 2009b, 2012).

As part of its efforts to develop a stronger military presence in the borderland regions the army has also sought to promote the development large of numbers of militia groups. The expansion of militias, nominally aligned to Army, is one of the most significant but underanalysed developments in Shan State, with one informant estimating that in 2010 in Northern Shan State alone in there were approximately four hundred militias with over eight thousand men and with reserves of more than sixteen thousand men. ${ }^{8}$ Militia groups provide a costeffective way for the Army to increase its manpower, whilst apparently providing an expendable frontline for the Army in its ongoing offensives against insurgent groups and in its efforts to confiscate land and securitise areas ear-marked for large-scale development projects. For example, in the areas surrounding the site of the hydropower Shweli Dam 1, in Namkham Township, Northern Shan State, state-backed militia groups (such as the Mantong and Pansay militias) appear to have played an important part in confiscating land, relocating an estimated fifteen thousand villagers and securitising the dam site (PYNG 2007; TSYO 2011). It is a very similar story around other development sites in Shan state, such as the Upper Thanlwin, Tasang and Upper Paugluang Dams (BEWG 2012; SWAN 2010; TNI 2012). The expansion of militia groups also adheres to the Army's 'divide and rule' strategies, pitting locally-formed militias against insurgent groups operating in the same area, weakening the unity of any form of ethnicity/identity-based opposition to the state.

In Shan State the Army has clearly sought to institutionalise order through the creation of decentralised, sub-national forms of limited access orders, in which promises of protection, access to resources, and control over checkpoints and border gates are used to maintain the loyalty of these militia groups. Drug revenues remain fundamentally important in lubricating these relationships and it seems clear that "while the regime is seeking to paint its manoeuvres against the ceasefire groups as a crusade against drugs, it is simultaneously building up security units that are just as notorious for drug production' (PWO 2006, 10). This analysis is corroborated by the fact that in the November 2010 general election at least four militia leaders notorious for their involvement in the drugs trade were elected in Shan State North as representatives of the government-backed Union Solidarity and Development Party (USDP) (Hseng Khio Fah 2010; SHAN 2011).

\section{Counter-movement}

Whilst liberal state-building policy has emphasised the dangers posed by fragile states, it is equally true that processes of state-building, involving the consolidation of the means of violence and extraction, pose profound risks and challenges to many social groups who may view state encroachment as a greater threat than the absence of formal state institutions. As Christopher Clapham (2004) powerfully argues:

\footnotetext{
${ }^{8}$ Interview with a Burmese researcher, Chiang Mai, $21^{\text {st }}$ June 2011
} 
This is the Accepted Manuscript of a book chapter published by Ashgate in Oliver Charnoz, Virginie Diaz Pedregal and Alan L. Kolata (eds). Local Politics, Global Impacts: Steps to a Multi-Disciplinary Analysis of Scales (Global Governance Series), 2015: https://www.routledge.com/Local-PoliticsGlobal-Impacts-Steps-to-a-Multi-disciplinary-Analysis/Charnoz-Pedregal/p/book/9781472460509 Accepted version downloaded from SOAS Research Online: http://eprints.soas.ac.uk/25341/

From the viewpoint of the indigenous peoples, on whom states were imposed, this process can readily be seen to have brought with it very significant costs, in social, economic, and political terms. The state-centred and state-supporting literature of political science has been so heavily concerned with emphasizing the benefits of statehood that the other side of the account has gone almost unnoticed (...). The social costs of statehood, and particularly of modern statehood, include the sacrifice of identities and structures that are inimical to the hierarchies of control that states seek to impose" (Clapham 2004, 86, cited in Boege et al 2008, $5-6)$

The highly lucrative nature of the drug trade, the fact that the state is rarely able to prevent extraction or impose a monopoly over the means of extraction, and the fact that wellestablished trade networks connect remote areas to external markets, has ensured that drugs continue to offer a valuable source of revenue for those opposing state encroachment and the processes of enclosure and primitive accumulation underpinning agrarian transitions. Most obviously, drugs have provided revenues for armed insurgency groups in Shan State fighting against the government. Although the highly politicized nature of involvement in the drug trade has led many groups to publicly distance themselves from involvement in an attempt to avoid de-legitimising their fight against the government, taxation on drug cultivation and trafficking continue to provide an important revenue stream for opposition groups (TNI 2012, 14-16). As a valuable cash crop that can be grown in remote areas drugs also offer an opportunity for more localised forms of "surreptitious resistance" (Scott 1990, 200), seemingly offering households a way of evading the centripetal forces of processes of state territorialisation, to escape military aggression and forced relocation programmes, and to continue to survive in areas where the growth of commercial agriculture has reduced land tenure security and limited the scope for more extensive forms of agriculture.

\section{Brokerage}

Attempts to minimize both the need to employ violent coercion and the threat of inciting counter-movements, means the state may commonly look to work through powerful local actors who prove themselves able to manage the interface between the central state and their communities in ways which allow the state to "reach down" into the "peripheries' (Wolf 1956, 1065). Although poorly understood, it is through such brokerage that the state may first find a foothold in areas where its authority has traditionally been subservient to that of powerful local actors. Within drug-producing regions the drug trade has invariably become an important foundation of local power structures, in which powerful actors manage taxation networks, trade routes, access to transnational finance, and coercive power. This places such actors at the "synapses" (Wolf 1956, 1071) between local and central networks of power, enabling them to act as brokers, benefitting from state patronage whilst looking to translate the state's penetration into borderland regions in ways which preserve their own interests. This is certainly the case in Burma where the drug trade has become a particularly important channel through which the modalities of interaction between these various social scales are experienced and has thus become an important arena in which processes of state-building and economic transformation are negotiated. 
This is the Accepted Manuscript of a book chapter published by Ashgate in Oliver Charnoz, Virginie Diaz Pedregal and Alan L. Kolata (eds). Local Politics, Global Impacts: Steps to a Multi-Disciplinary Analysis of Scales (Global Governance Series), 2015: https://www.routledge.com/Local-PoliticsGlobal-Impacts-Steps-to-a-Multi-disciplinary-Analysis/Charnoz-Pedregal/p/book/9781472460509 Accepted version downloaded from SOAS Research Online: http://eprints.soas.ac.uk/25341/

Since the early 1990s the government and the army have sought to increase the opportunity costs of violence and encourage co-operation by offering ceasefire groups and militias in Shan State preferential access to the drug economy in return for a cessation of hostilities and a promise to sever all ties with groups still in opposition. Over the past twenty years the state has sought to create a system of rents within the drug economy through numerous mechanisms. Most obvious has been the state's willingness to offer legal impunity to groups involved in the drugs trade following their signing of ceasefire agreements. This was shown most clearly in early 2005 following the indictment of eight leaders of the UWSA by a Brooklyn federal grand jury in the United States (Kramer 2007, 54). The state's refusal to arrest any of those charged or to end its intimate business links with the corporations they controlled demonstrated the level of protection the government was willing to offer to former insurgent groups who had 'returned to the legal fold'. Of greater importance has been the state's readiness to offer money-laundering services. Since 1989 state-controlled banks have accepted deposits of dubious origin without question, subject to a 'whitening tax' initially levied at 40 per cent and later reduced to 25 per cent (Lintner and Black 2009, 122; Lintner 2000, 187). In return for greater co-operation and support, state actors, at both the regional and national level, have also offered business permits and government contracts to organisations known to be involved in the drugs trade, providing a legitimate front through which they are then able invest income derived illegally. (see Meehan 2011, 389-99 for a more detailed discussion of this point.)

Over the past twenty years these strategies have greatly aided the state's efforts to gain greater control over the means of violence in Shan State. The incentives offered by the state have converted many former rebel groups into proxy state actors, enabling the Burmese Army to concentrate its forces against those groups that have refused to enter into ceasefire agreements, often supported by former insurgent armies. The deals brokered between the state and powerful local actors have also strengthened the state's economic position in a number of ways. Firstly, by offering legal impunity, money-laundering services and business opportunities the state has been able to effectively direct a far greater proportion of drug revenue inwards. This 'stemming of capital flight' and the channelling of revenue into the legal economy has been one of the most important but least reported changes to Burma's political economy over the last two decades (Snyder 2006, 961; Lintner 1998). Secondly, through these bargaining processes the state has gained far greater control over both crossborder trade with China and Thailand and the exploitation of natural resources in Shan State.

Shan State's growing integration into regional markets offers hugely lucrative opportunities to incorporate the area's abundant natural resources into global commodity chains. Within this environment the drug trade appears to have been viewed as the quickest way to accumulate large amounts of capital, providing the financial means with which to invest in new, legal, economic opportunities. ${ }^{9}$ This was especially apparent in the early 1990 s

\footnotetext{
${ }^{9}$ These processes are not new. Carl Trocki's (1999) study of the role of opium in Empire-building in Asia powerfully emphasizes the centrality of illicit economies to processes of capital accumulation and class formation which have underpinned both the rise of capitalism and the creation of the modern state (xiv). Opium, he argues, served both to "entrap labour forces" through the monetarization of subsistence lifestyles, whilst also generating vast amounts of surplus wealth which "fed the institutions that accumulated it", namely the banking and financial sectors, insurance and infrastructural developments (173).
} 
This is the Accepted Manuscript of a book chapter published by Ashgate in Oliver Charnoz, Virginie Diaz Pedregal and Alan L. Kolata (eds). Local Politics, Global Impacts: Steps to a Multi-Disciplinary Analysis of Scales (Global Governance Series), 2015: https://www.routledge.com/Local-PoliticsGlobal-Impacts-Steps-to-a-Multi-disciplinary-Analysis/Charnoz-Pedregal/p/book/9781472460509 Accepted version downloaded from SOAS Research Online: http://eprints.soas.ac.uk/25341/

following the SLORC's efforts to reform the dysfunctional state-controlled economy. In an attempt to redress decades of stalled growth the government launched a partial liberalisation of the country's economy, enabling the emergence of a small number of private banks and the development of a small private industrial sector, mostly focused on the construction industry and import/export enterprises (Turnell 2002; Turnell 2009, 256-296). ${ }^{10}$

The Hong Pang Group, now one of Burma's largest conglomerates with over thirty subsidiaries, offers an insightful example (Lintner and Black 2009, 117-8). It is owned by Wei Xuegang (Wei Hseuh-Kang), a leading figure in the UWSA and formerly the General Commander of its Southern Command, whose troops have launched joint offensives with the Burmese Army against the SSA-S (Ko Lin Chin 2009, 140). A former associate of the late Khun Sa, Burma's most notorious drug-lord (McCoy 1999), Wei is wanted in both the United States and Thailand on drug-trafficking charges and is "believed to be the kingpin of Burma's methamphetamine business" (Ko Lin Chin 2009, 140). Described as a "real friend" in 2001 by Prime Minister General Thein Sein, then in charge of the Burma Army's Triangle Command (Lintner \& Black, p.98), Wei came to enjoy close links with the government in the 1990s (Meehan 2011, 392). The Hong Pang Group has gained permits for large scale logging and commercial agriculture projects in Shan State as well as being contracted to build a highway between Tachilek and Kengtung. It has also been involved in deforestation and infrastructure development around numerous dam sites across Shan State, notably the Tasang Dam on the Salween River (Shan Sapawa Environmental Organisation 2009, 14), all of which have led the company to be described as "the biggest money-laundering operation in South-east Asia today" (Lintner and Black 2009, 117). The case of the Hong Pang Group is by no means unique and many of Burma's largest corporations appear to have had roots in the country's shadow economy (For a more detailed analysis see Meehan 2011, 392-5; also ALTSEAN-Burma 2004, 65-80, 113-15; Irrawaddy 2001; Maung Aye 2011; Snyder 2006).

Thus, whilst the complex matrix of deals brokered between the government and powerful local actors has enabled the state far greater penetration of the borderlands, it has also provided local actors with opportunities to consolidate and legitimize their wealth by investing in the legal economy and seeking political office. These processes of "diversification" and "graduation" (Goodhand and Mansfield 2010, 26) have served both to strengthen the political coalitions underpinning limited access orders, whilst the economic opportunities they confer have provided further impetus to generate income through the drug trade.

It should be noted, however, that the long-term political outcomes of these processes of brokerage still remain unclear. On the one hand, Kevin Woods (2011a) has powerfully argued that by directing transnational finance into resource-rich upland areas in Kachin State, the Burmese government has been able to establish military-private partnerships which have spearheaded both processes of primitive accumulation and increased state legibility, thus converting the state's de jure sovereignty into de facto control. In these militarized

\footnotetext{
${ }^{10}$ A hypothesis still to be tested is whether the a direct link can be drawn between the SLORC's partial liberalisation of the economy, especially its decision to allow the development of a small private banking sector, and the huge spike in drug production in the 1990s.
} 
This is the Accepted Manuscript of a book chapter published by Ashgate in Oliver Charnoz, Virginie Diaz Pedregal and Alan L. Kolata (eds). Local Politics, Global Impacts: Steps to a Multi-Disciplinary Analysis of Scales (Global Governance Series), 2015: https://www.routledge.com/Local-PoliticsGlobal-Impacts-Steps-to-a-Multi-disciplinary-Analysis/Charnoz-Pedregal/p/book/9781472460509 Accepted version downloaded from SOAS Research Online: http://eprints.soas.ac.uk/25341/

borderland areas, where access to land and resources remains highly contested, national and transnational corporations have sought to promote functioning state institutions, viewing these as the most viable way to "fix, regulate and expand capitalist spaces" (p.751) in which they increasingly look to the state to uphold and enforce their property 'rights'. In contrast, however, MacLean's (2008) study on Burma's "extractive enclaves", offers a far more ambiguous and paradoxical analysis. It argues that whilst brokerage strategies have provided the state with greater access to the country's borderland regions, they have also led to the diffusion of power into local networks, over which the state has found it increasingly difficult to centralize any form of control. Brokerage has created complex and overlapping networks of "Tatmadaw [army] field battalions, cease-fire groups, state-owned enterprises, and local entrepreneurs", creating "mosaics of territorial control" (Hardin 2002, ii), over which the state has found it increasingly difficult to consolidate its control over commodities and populations (MacLean 2008, 141).

\section{Scaling up: How engaging with local politics offers alternative perspectives on global counter-narcotics strategies}

This study has demonstrated the inextricable links between the drugs trade and the local political and economic context in Burma's eastern borderlands within which it operates. It argues that global counter-narcotics strategies must begin with a proper conceptualisation of how the state actually functions at the local level and an understanding of the spatial dimensions of state power, which recognises the ways in which drug-producing borderland regions may become fundamentally important to processes of state consolidation. The symbiotic relationship that is perceived to exist between counter-narcotics strategies, peacebuilding and state-building, in which strict law enforcement and drug eradication is viewed as a means by which to target the revenue of 'greedy' rebels and in doing so strengthen government institutions in fragile states, also needs to be questioned (Goodhand and Mansfield 2010, 35). Instead, greater emphasis must be given to the ways in which illicit economies can become embedded in the very processes of state-building and economic 'development', which it is often assumed will lead to a reduction in drug production. This paper also demonstrates how the entrance of international actors and transnational capital flows into source regions may intensify social conflict in ways that re-shape the political economy of drugs and continue to drive production.

The impact of China's Opium Substitution programme in Northern Burma provides a worrying example of how such oversights can lead to severe unintended consequences. In an attempt to reduce the amount of heroin crossing the border the Chinese government launched the Opium Replacement Fund in 2006, offering subsidies, tax waivers and import quotas to Chinese companies which established alternative development enterprises in North-eastern Burma. The fund has provided impetus to the development of commercial agriculture, especially rubber, often through public-private partnerships with the Burmese government (TNI 2012). This 'frontier capitalism' has been accompanied by violent land grabs, forced relocation of borderland populations, extensive deforestation, and a significant rise in drug production (TNI 2012, 4,13-14; Woods 2011b). Increased opium cultivation appears to have become an increasingly important livelihood survival strategy for smallholders faced with the prospect of heightened land tenure and food insecurity (TNI 2010, 2). Furthermore, the revenues derived from the drug trade have seemingly been incorporated into the ongoing 
This is the Accepted Manuscript of a book chapter published by Ashgate in Oliver Charnoz, Virginie Diaz Pedregal and Alan L. Kolata (eds). Local Politics, Global Impacts: Steps to a Multi-Disciplinary Analysis of Scales (Global Governance Series), 2015: https://www.routledge.com/Local-PoliticsGlobal-Impacts-Steps-to-a-Multi-disciplinary-Analysis/Charnoz-Pedregal/p/book/9781472460509 Accepted version downloaded from SOAS Research Online: http://eprints.soas.ac.uk/25341/

processes of coercion, countermovement and brokerage surrounding attempts to integrate Burma's border regions into regional commodity markets, creating an environment in which the economic 'reforms' designed to reduce opium cultivation have become an important factor in accounting for the increase in drug production since 2006.

The complex relationship between drugs and the politics of state-building and economic transformation in Burma's eastern borderlands raises the question of whether a counternarcotics strategy designed at the global level can ever be successful. Although providing an adequate answer to this question is beyond the scope of this chapter, the research presented here emphasizes the ways in which a scalar analysis offers insights into why, and at which level, global strategies often fail, by understanding how they become 'translated' in local contexts. In particular, this study has sought to demonstrate that whilst the challenges posed by the illicit drugs trade may be experienced on a global scale, they can rarely be properly understood and addressed solely at the global level. Such an approach invariably encourages reified, depoliticized, institutionalist responses to problems which are inherently political.

\section{References}

Abrams, P., 1988. "Notes on the Difficulty of Studying the State (1977)." Journal of Historical Sociology 1: 58-89.

Agnew, J., 2008. "Borders on the Mind: Re-framing border thinking." Ethics \& Global Politics 1. Agnew, J., Corbridge, S., 1995. Mastering Space: Hegemony, territory and international political economy. (Routledge: London)

ALTSEAN-Burma, 2004. A failing grade: Burma's drug eradication efforts. (Bangkok: ALTSEAN-Burma)

----- 2006. ATS: A Need for Speed. (Bangkok: ALTSEAN-Burma)

Appadurai, A., 2001. Globalization. (Duke University Press: Durham, NC)

Ballentine, K., Sherman, J., 2003. "Introduction." In The Political Economy of Armed Conflict: Beyond greed and grievance, edited by Ballentine, K., Sherman, J. (London: Lynne Reinner Publishers)

Ballentine, K., Nitzschke, H., 2005. "Introduction.” In Profiting from Peace: Managing the resource dimensions of civil war., edited by Ballentine, K., Nitzschke, H. (London: Lynne Reinner Publishers)

Ballve, T. 2011, "Territory by dispossession: Decentralization, Statehood, and the Narco LandGrab in Colombia.", Paper presented at the International Conference on Global Land Grabbing., 6-8 April 2011

Barney, K., 2008, "China and the Production of Forestlands in Laos: A political ecology of transnational enclosure." In Taking Southeast Asia to Market: Commodities, Nature, and People in the Neoliberal Age., edited by Nevins, J., and Peluso, N., (Cornell University Press: Ithaca)

Baud, M., Schendel, W. van, 1997. "Toward a Comparative History of Borderlands." Journal of World History 8: 211-242.

Berdal, M., Malone, D., eds. 2000. Greed and Grievance: Economic agendas in civil wars. (London: Lynne Reinner Publishers) 
This is the Accepted Manuscript of a book chapter published by Ashgate in Oliver Charnoz, Virginie Diaz Pedregal and Alan L. Kolata (eds). Local Politics, Global Impacts: Steps to a Multi-Disciplinary Analysis of Scales (Global Governance Series), 2015: https://www.routledge.com/Local-PoliticsGlobal-Impacts-Steps-to-a-Multi-disciplinary-Analysis/Charnoz-Pedregal/p/book/9781472460509 Accepted version downloaded from SOAS Research Online: http://eprints.soas.ac.uk/25341/

Boege, V., Brown, M., Clements, K., Nolan, A., 2008. "On Hybrid Political Orders and Emerging States: State formation in the context of fragility." In Berghof Handbook Dialogue 8 (Berlin: Berghof Research Center for Constructive Conflict Management)

Brenner, N., 1999. "Beyond State-Centrism? Space, Territoriality, and Geographical Scale in Globalization Studies." Theory and Society 28(1): 39-78

Brenner, N., Elden, S., 2009, "Henri Lefebvre on State, Space, Territory.", International Political Sociology, 3: 353-377

Brown, C., 1999. "Burma: The Political Economy of Violence.” Disasters 23: 234-256

Burma Environmental Working Group (BEWG), 2011. Burma's environment: people, problems, policies.

Callahan, M., 2007a. "Political Authority in Burma's Ethnic Minority States: Devolution, occupation, and coexistence.” In Policy Studies 31 (Southeast Asia) (Washington, DC: EastWest Center; Singapore: ISEAS)

------2007b. "Of Kyay-zu and Kyet-zu: The military in 2006." In Myanmar: The State, Community and the Environment., edited by Skidmore, M., Wilson, T., (Canberra: Asia Pacific Press)

Clapham, C., 2004. "The Global-Local Politics of State Decay." In When States Fail: Causes and consequences edited by Rotberg, R. (Princeton: Princeton University Press)

Collier, P., 2000. "Doing Well out of War: An economic perspective.", in Greed and Grievance: Economic agendas in civil wars., edited by Berdal, M., Malone, D. (London: Lynne Reinner Publishers)

Collier, P., Hoeffler, A., 1998. "On the Economic Causes of War.” Oxford Economic Papers 50(4): 563-73.

Collier, P., Elliot, V., Hegre, H., Hoeffler, A., Reyna-Quirol, M., Sambanis, N., 2003. Breaking the Conflict Trap. (Washington, D.C.: World Bank and Oxford University Press)

Cornell, S., 2005. "The Interaction of Narcotics and Conflict." Journal of Peace Research 42(6)

Cramer, C., 2006. Civil War Is Not a Stupid Thing. Accounting for Violence in Developing Countries. (London: Hurst \& Company)

Cramer, C., Richards, P., 2011. "Violence and War in Agrarian Perspective." Journal of Agrarian Change 11(3)

De Waal, A., 2009. "Mission without end? Peacekeeping in the African political marketplace." International Affairs 85(1): 99-113.

Di John, J., 2008. "Conceptualising the Causes and Consequences of Failed States: A Critical Review of the Literature.” LSE/DESTIN Crisis States Research Working Paper 25 (Series 2)

European Union (E.U.), 2005. "European Consensus on Development." Official Journal of the European Union.

Ghani, A., Lockhart, C., 2008. Fixing Failed States. A Framework for Rebuilding a Fractured World. (Oxford: Oxford University Press)

Giustozzi, A., 2011. The Art of Coercion: The primitive accumulation and management of coercive power. (Hurst: London)

Goodhand, 2008a. "War, Peace and the Places in Between: Why borderlands are central." In Whose Peace? Critical Perspectives on the Political Economy of Peacebuilding. Edited by Pugh, M., Cooper, N., Turner, M., 225-244 (London: Palgrave) 2008b. "Corrupting or Consolidating the Peace? The drugs economy and post-conflict peacebuilding in Afghanistan." International Peacekeeping 15(3): 405-23

------ 2009, "Bandits, Borderlands and Opium Wars: Afghan statebuilding viewed from the Margins.” DIIS Working Paper 26 (Copenhagen: Danish Institute for International Studies) 
This is the Accepted Manuscript of a book chapter published by Ashgate in Oliver Charnoz, Virginie Diaz Pedregal and Alan L. Kolata (eds). Local Politics, Global Impacts: Steps to a Multi-Disciplinary Analysis of Scales (Global Governance Series), 2015: https://www.routledge.com/Local-PoliticsGlobal-Impacts-Steps-to-a-Multi-disciplinary-Analysis/Charnoz-Pedregal/p/book/9781472460509 Accepted version downloaded from SOAS Research Online: http://eprints.soas.ac.uk/25341/

Goodhand, J., Mansfield, D., 2010. "Drugs and (Dis)order: A study of the opium trade, political settlements and state-making in Afghanistan." LSE/DESTIN Crisis States Research Working Paper 83 (series 2)

Grossman, H., 1991. "A General Equilibrium Model of Insurrections." American Economic Review 81: 912-921

Hardin, R., 2002. "Concessionary Politics in the Western Congo Basin: History and culture in forest use.", Environmental Governance in Africa Working Papers Series 6 (Washington D.C.: World Resources Institute)

Heyman, J., Smart, A., 1999. "States and Illegal Practices: An overview." In States and Illegal Practices. Edited by Heyman,J. (Oxford: Berg)

Hseng Khio Fah, 2010. “Burma's Druglords become Lawmakers.” Shan Herald Agency for News

Hershleifer, J., 1995. "Theorizing about Conflict." In Handbook of defense economics, Vol. 1. Edited by. Hartley, K., Sandler, T. (Amsterdam: North-Holland)

----- 2001. The Dark Side of the Force: Economic foundations of conflict theory. (Cambridge: Cambridge University Press)

Irrawaddy, 2001. “Above it all.”, Irrawaddy Magazine, 9:2

Jelsma, M., Kramer, T., 2005. "Downward Spiral: Banning opium in Afghanistan and Burma." Drugs and Conflict, debate papers 12: 3-23 (Amsterdam: Transnational Institute)

Keen, D., 1998. "The Economic Functions of Violence in Civil Wars." Adelphi Paper 320 (Oxford: IISS/Oxford University Press)

Ko-lin Chin, 2009. The Golden Triangle: Inside Southeast Asia's drug trade. (Ithaca and London: Cornell University Press)

Kramer, T., 2007. "The United Wa State Party: Narco-army or ethnic nationalist party.", Policy Studies 38 (Southeast Asia) (Washington, DC: East-West Center; Singapore: ISEAS)

Kudo, T., 2008. "Myanmar's Economic Relations with China: Who benefits and who pays?" In Dictatorship, disorder and decline in Myanmar. Edited by Skidmore, M., Wilson, T.

(Canberra: Australian National University Press)

Lefebvre, H., 1991. The Production of Space. (Oxford: Blackwell)

Lintner, B., 1990. The Rise and Fall of the Communist Party of Burma. (London: Cornell University Press)

1998. "Drugs and Economic Growth: Ethnicity and exports." In Burma: Prospects for a democratic future. Edited by Rotberg, R. (Washington, DC: The World Peace Foundation)

----- 2000. "The Golden Triangle Opium Trade: An overview." Asia Pacific Media Services.

Lintner, B., Black, M., 2009. Merchants of Madness: The methamphetamine explosion in the Golden Triangle. (Chiang Mai: Silkworm Books)

Lujala, P., Gledistch, N., Gilmore, E., 2005. "A Diamond Curse? Civil War and a Lootable Resource." The Journal of Conflict Resolution 49(4): 538-562

Lund, C., 2006. "Twilight Institutions: An Introduction." Development and Change 37: 673-684

----- "Fragmented Sovereignty: Land reform and dispossession in Laos." Journal of Peasant Studies 38: 885-905.

MacLean, K., 2008, "Sovereignty after the Entrepreneurial Turn: Mosaics of control, commodified spaces, and regulated violence in contemporary Burma." In Taking Southeast Asia to Market: Commodities: Nature, and People in a Neoliberal Age., Edited by Peluso, N., Nevins, J. (Ithaca: Cornell University Press)

Mann, M., 2009. "The autonomous power of the state: its origins, mechanisms and results.", European Journal of Sociology 25:185-213 
This is the Accepted Manuscript of a book chapter published by Ashgate in Oliver Charnoz, Virginie Diaz Pedregal and Alan L. Kolata (eds). Local Politics, Global Impacts: Steps to a Multi-Disciplinary Analysis of Scales (Global Governance Series), 2015: https://www.routledge.com/Local-PoliticsGlobal-Impacts-Steps-to-a-Multi-disciplinary-Analysis/Charnoz-Pedregal/p/book/9781472460509 Accepted version downloaded from SOAS Research Online: http://eprints.soas.ac.uk/25341/

Massey, D., 2009, “Concepts of space and power in theory and in political practice.", Documents d'anàlisi geogràfica 55:15-26

Maung Aye, 2011. "Not just standing in the shadows.", The Irrawaddy., 14 ${ }^{\text {th }}$ March 2011

McCoy, A., "Requiem for a drug lord: State and commodity in the career of Khun Sa." In States and Illegal Practices. Edited by Heyman, J. (Oxford: Berg)

------ 2004. "The Stimulus of Prohibition: A critical history of the global narcotics trade." In Dangerous Harvest: Drug plants and the transformation of indigenous landscapes. Edited by Steinberg,M., Hobbs,J., Mathewson, K. (Oxford: Oxford University Press)

Meehan, P., 2011. "Drugs, Insurgency and State-building in Burma: Why the drugs trade is central to Burma's changing political order." Journal of Southeast Asian Studies 42(3): 376-404

Migdal, J. (2001), State in Society: Studying how states and societies transform and constitute one another. (Cambridge University Press: Cambridge)

Milliken, J., Krause, K., 2002. "State Failure, State Collapse, and State Reconstruction: Concepts, lessons and strategies." Development and Change 33: 753-774.

Myint-U, T., 2006, The River of Lost Footsteps: Histories of Burma. (Farrar, Straus and Giroux: New York)

Nevins, J., Peluso, N., 2008. Taking Southeast Asia to Market: Commodities, nature, and people in the neoliberal age. (Cornell University Press: Ithaca)

Newman, D., Paasi, A., 1998. "Fences and Neighbours in the Postmodern World: Boundary Narratives in Political Geography." Progress in Human Geography 22: 186-207.

North, D., Wallis, J., Webb, S., Weingast, B., 2007. "Limited Access Orders in the Developing World: A new approach to the problems of development." World Bank Policy Research Working Paper 4359

North, D., Wallis, J., Weingast, B., 2009. Violence and Social Orders: A conceptual framework for interpreting recorded human history. (Cambridge University Press, Cambridge; New York)

Nugent, D., 1999. "State and Shadow State in Northern Peru circa 1900: Illegal political networks and the problems of state boundaries." In States and Illegal Practices. Edited by Heyman, J. (Oxford: Berg)

Palaung Women's Organisation (PWO), 2006. Poisoned Flowers. (Mae Sot: PWO)

----- 2010. Poisoned Hills: Opium cultivation surges under government control in Burma. (Mae Sot: PWO)

----- 2011. Still Poisoned, Opium Cultivation Soars in Palaung Areas under Burma's New Regime. (Mae Sot: PWO)

Palaung (Ta'ang) Youth Network Group (PYNG), 2007. Under the Boot: The Burma Army clears the way for Chinese Dams on the Shweli River.

Peluso, N.L., Lund, C., 2011. "New Frontiers of Land Control: Introduction." Journal of Peasant Studies 38: 667-681.

Renard, R.D., 1996. The Burmese Connection. Illegal drugs and the making of the Golden Triangle. (Boulder: Lynne Rienner Publishers)

Ross, M., 2004. "How do Natural Resources Influence Civil War? Evidence from thirteen cases." International Organization 58: 35-67

Scott, J., 1990. Domination and the Arts of Resistance: Hidden transcripts. (New Haven: Yale University Press)

------ The Art of Not Being Governed: An Anarchist History of upland Southeast Asia. (New Haven: Yale University Press) 
This is the Accepted Manuscript of a book chapter published by Ashgate in Oliver Charnoz, Virginie Diaz Pedregal and Alan L. Kolata (eds). Local Politics, Global Impacts: Steps to a Multi-Disciplinary Analysis of Scales (Global Governance Series), 2015: https://www.routledge.com/Local-PoliticsGlobal-Impacts-Steps-to-a-Multi-disciplinary-Analysis/Charnoz-Pedregal/p/book/9781472460509 Accepted version downloaded from SOAS Research Online: http://eprints.soas.ac.uk/25341/

Selth, A., 2007. Burma's Armed Forces: Power without Glory. (Norwalk: Eastbridge)

SHAN, 2003. Showbusiness. Rangoon's “War on Drugs” in Shan State.

------ 2005. Hand in Glove, The Burma Army and the Drug Trade in Shan State. (Chiang Mai: Shan Herald Agency for News)

----- 2011. Shan Drug Watch, Issue 4.

Shan Sapawa Environmental Organisation, 2009. Roots and Resilience: Tasang Dam threatens war torn Shan communities.

Shan Women's Action Network (SWAN), 2010. Burma Army Tracks across Shan State.

Snyder, R., 2006. "Does Lootable Wealth Breed Disorder? A political economy of extraction framework." Comparative Political Studies 39: 943-968

Ta'ang Students and Youth Organization (TSYO), 2011. Shweli Under Seige: Dams proceed amid war in Burma.

Taylor, R., 2008. The state in Myanmar. (London: Hurst)

Tilly, C., 1990. Coercion, Capital, and European States, AD 990-1992. (Oxford: Blackwell Publishers)

TNI, 2009a. Burma: Neither War Nor Peace: The Future of the cease-fire agreements in Burma.

---- 2009b. "From Golden Triangle to Rubber Belt? The Future of Opium Bans in the Kokang and Wa Regions." Drug Policy Briefing 29

------, 2010. “Alternative Development or Business as Usual ?: China's Opium Substitution Policy in Burma and Laos.", Drug Policy Briefing, No. 33

2012. Financing Dispossession: China's Opium Substitution Programme in Northern Burma.

Trocki, C., 1999. Opium, Empire and the Global Political Economy: A study of the Asian opium trade. (New York: Routledge)

Tullis, L., 1995. Unintended Consequences: Illegal drugs and drug policies in nine countries. (London: Lyne Rienner Publishers)

Turnell, S., 2002. "Reforming the Banking System in Burma: A Survey of the Problems and Possibilities.", Washington Technical Advisory Network of Burma, Working Paper 7, 2008. "Myanmar's Economy in 2006." In Dictatorship, Disorder and Decline in Myanmar. Edited by Skidmore, M.,Wilson, T. (Canberra: Australian National University Press) 2009. Fiery Dragons: Banks, Moneylenders and Microfinance in Burma. (Copenhagen: NIAS Press)

United Nations, 1998. Political Declaration, General Assembly 20th Special Session, 9th Plenary Meeting, June 10, 1998 (A/RES/S-20/2), par. 19 and par. 14.

United Nations Office on Drugs and Crime (UNODC), 2010a. Myanmar: Situation assessment on Amphetamine-Type Stimulants. (Bangkok: UNODC)

----- 2010b. Opium Poppy Cultivation in South-East Asia - Lao PDR, Myanmar. (Bangkok: UNODC)

------ 2010c. World Drug Report 2010 (New York: UNODC)

van der Veen,H., 2002. "The War on Drugs in the Creation of the New World (dis)order." In Shadow Globalization, Ethnic Conflicts and New Wars: A political economy of intra-state war. Edited by Jung, D. (London: Routledge)

Wolf, E., 1956. "Aspects of Group Relations in a Complex Society: Mexico." American Anthropologist, 58(6): 1065-1078 
This is the Accepted Manuscript of a book chapter published by Ashgate in Oliver Charnoz, Virginie Diaz Pedregal and Alan L. Kolata (eds). Local Politics, Global Impacts: Steps to a Multi-Disciplinary Analysis of Scales (Global Governance Series), 2015: https://www.routledge.com/Local-PoliticsGlobal-Impacts-Steps-to-a-Multi-disciplinary-Analysis/Charnoz-Pedregal/p/book/9781472460509 Accepted version downloaded from SOAS Research Online: http://eprints.soas.ac.uk/25341/

Woods, K., 2011a. “Ceasefire Capitalism: Military-private partnerships, resource concessions and military-state building in the Burma-China borderlands. Journal of Peasant Studies 38: 747770 .

2011b. "Rubber planting and military-state making: military-private partnerships in northern Burma.", New Mandala, February $4^{\text {th }} 2011$ 